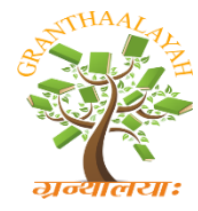

INTERNATIONAL JOURNAL OF RESEARCH GRANTHAALAYAH

A knowledge Repository

Social

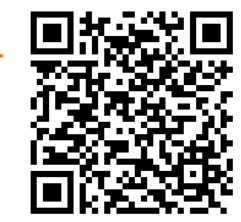

\title{
COMPARATIVE STUDY RELATED TO IMPACT OF TEACHER MOTHER FOR TODDLERS
}

\author{
Dr. Paras Jain ${ }^{1}$, Roshni Billaiya ${ }^{2}$ \\ ${ }^{1}$ Director, Silicobyte Katni Degree College, Dikshabhumi Campus, Adharkap, Katni (M.P), \\ India \\ ${ }^{2}$ Registrar, Silicobyte Katni Degree College, Dikshabhumi Campus, Adharkap, Katni (M.P), \\ India
}

\begin{abstract}
It is widely accepted that teacher's expectations affect students' achievement. A teacher knows very well how to communicate knowledge to students according to their age, class and mental level of children. Present study is focused on finding of impact of teacher mother and non teacher mother on progress of children.
\end{abstract}

Keywords: Teacher's Expectations; Academics; Student Achievement.

Cite This Article: Dr. Paras Jain, and Roshni Billaiya. (2018). "COMPARATIVE STUDY RELATED TO IMPACT OF TEACHER MOTHER FOR TODDLERS." International Journal of Research - Granthaalayah, 6(1), 523-525. 10.29121/granthaalayah.v6.i1.2018.1662.

\section{Introduction}

A mother is considered as first teacher of child and a teacher treat student as her child. A mother as a teacher knows the academic need of child and inspires him to get achievement. She knows the way to transmit the knowledge and to develop child's interest in studies and in creative works. A teacher mother has better understanding about emotions of child. The presence of a teacher mother with child effectively reduces their anxiety. A teacher mother is more capable mother for betterment of child. A successful teacher behaves like mother to understand their emotions.

\section{Objective of Study}

- Finding of impact of teacher mother on student academic progress

- Finding of impact of non teacher mother on student academic progress

- Finding of impact of teacher mother on student non academic progress

- Finding of impact of non teacher mother on student non academic progress 


\section{Hypothesis}

1) There is significant impact of teacher mother on academic progress of student.

2) There is significant impact of teacher mother on non academic progress of student.

3) There is no significant impact of non teacher mother on academic progress of student.

4) There is no significant impact of non teacher mother on non academic progress of student.

\section{Methodology}

Descriptive method was used for present study. 500 students of class I-V were randomly selected as sample. It consists of 125 rural male, 125 rural female, 125 urban male and 125 urban female. They were categorized according to status of working of mother. These students were tested using a self prepared questionnaire. Collected data was tabulated and analyzed using mean, standard deviation and $\mathrm{t}$ value as statistical tools.

\section{Finding and Analysis}

Table 1: Status of Academic and Non Academic Mean Value of Teacher and Non Teacher Mother

\begin{tabular}{|c|c|c|c|c|}
\hline \multirow[b]{2}{*}{ Status of Mother } & \multirow{2}{*}{ Student Progress } & \multicolumn{3}{|c|}{ Student Progress } \\
\hline & & Mean Value & Std. Deviation & t value \\
\hline \multirow{2}{*}{ Teacher Mother } & Academic & 63.8 & 1.07 & \multirow{2}{*}{0.88} \\
\hline & Non Academic & 54.3 & 0.92 & \\
\hline \multirow{2}{*}{ Non Teacher Mother } & Academic & 56.7 & 1.13 & \multirow{2}{*}{0.91} \\
\hline & Non Academic & 59.4 & 1.02 & \\
\hline
\end{tabular}

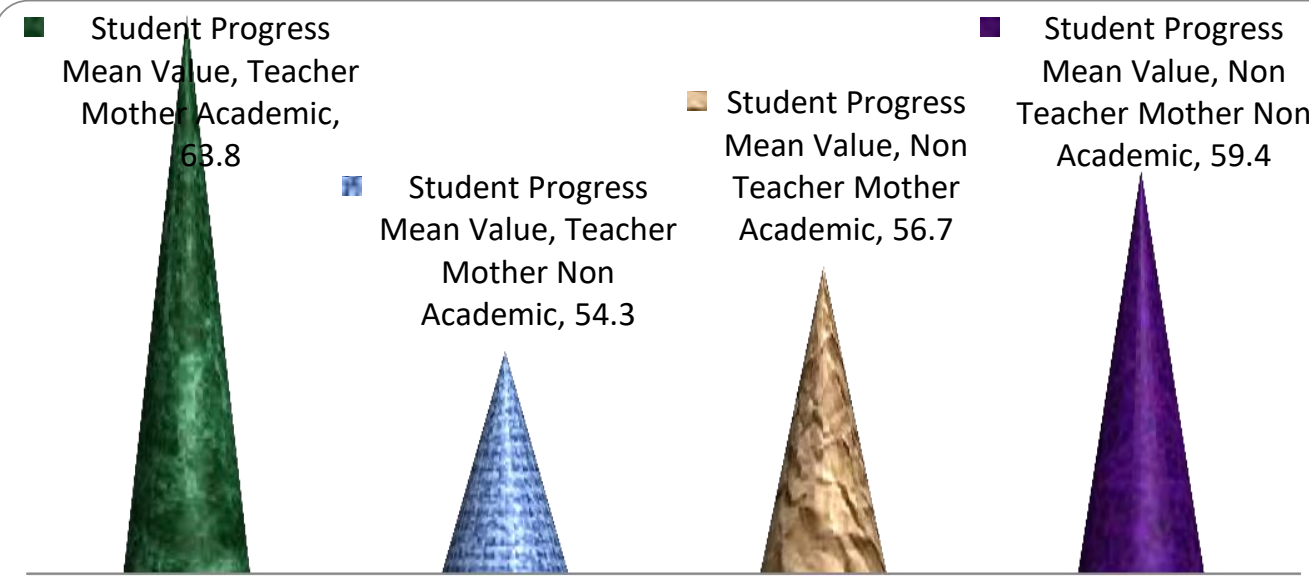

- Teacher Mother Academic Acalche

Teacher Mother Non Academic

$\square$ Non Teacher Mother Academic

- Non Teacher Mother Non Academic 


\section{Chart: Status of Academic and Non Academic Mean Value of Teacher and Non Teacher Mother}

Data shows that students of teacher mother have mean value 63.8 with standard deviation 1.07 and $t$ value calculated as 0.88 . This value is significant hence hypothesis 1 , there is a significant impact of teacher mother on academic progress of student is accepted.

Non academic mean value of teacher mother students is 54.3 with standard deviation 0.92 . Thus hypothesis 2 , there is significant impact of teacher mother on non academic progress of student is rejected.

Academic value of students having non teacher mother is 56.7 which is less for teacher mother. Standard deviation is 1.13 and calculated $t$ value is 0.91 . Therefore, hypothesis 3 , there is no significant impact of non teacher mother on academic progress of student is accepted.

Non academic progress mean value for non teacher mother student is 59.4 greater than the value for teacher mother. That's why hypothesis 4, there is no significant impact of non teacher mother on non academic progress of student is rejected.

\section{Conclusion}

Teacher mothers influence academic progress of children. A teacher mother influence student academic progress, hence academic results are better in case of teacher mother rather than non teacher mother. In case of non academic progress feedback of students having non teacher mother are better in comparison of teacher mother's child.

\section{References}

[1] Hughes, J., \& Kwok, O.K., Influence of Student-Teacher and Parent-Teacher Relationships on Lower Achieving Readers' Engagement and Achievement in the Primary Grades, J Educational Psychol. 99(1), Feb 2007.

[2] Goldenberg, The Limits of Expectations: A Case for Case Knowledge about Teacher Expectancy Effects", American Educational Research Journal, Volume 29, Number 3, May-June 1993.

[3] Claesson, M.A., Brice, R.A., Teacher/Mothers: Effects of a Dual Role, American Educational Research Journal, March 1989.

[4] James, J.H., Teachers as mothers in the elementary classroom: negotiating the needs of self and other, Journal of Gender and Education, Volume 22, Issue 5, 2010

*Corresponding author.

E-mail address: parasjainkatni@gmail.com 